\title{
Antigen processing sites in gp120 are conserved across HIV virus clades
}

\author{
B Yu*, SM O'Rourke, JF Morales, GP Tatsuno, KA Mesa, PW Berman \\ From AIDS Vaccine 2012 \\ Boston, MA, USA. 9-12 September 2012
}

\section{Background}

A puzzling observation in HIV vaccine research is the fact that recombinant gp120 is able to adsorb bNAbs from HIV+ patient sera, but unable to elicit such bNAbs. To account for its poor immunogenicity, we wondered if the epitopes recognized by bNAbs might be proteolyzed in vivo. Cathepsins $\mathrm{L}, \mathrm{S}$, and $\mathrm{D}$ are the major proteases responsible for antigen processing and presentation. Previously, we defined the cathepsin cleavage sites on $\mathrm{MN}$ rgp120 and found that they co-localized with epitopes recognized by bNAbs. Although examination of gp120 sequences suggested that these sites were conserved, the recognition motifs for cathepsins are poorly defined and it was important to verify their presence by protease digestion studies.

\section{Methods}

Purified gp120s from three clades of HIV were digested with cathepsins L, S, and D. These included envelope proteins from the from the 108060 (clade B), A244 (CRF01_AE) and 97001 (clade C) isolates. N-terminal sequencing was used to identify the cathepsin cleavage sites.

\section{Results}

When combined with the previous MN-rgp120 results, we found that 6 out of 10 cathepsin cleavage sites were conserved in four viruses from three different clades of HIV. We found that polymorphisms that inactivate cleavage sites often result in the formation of an alternate nearby site. Although cleavage is an ordered processing beginning in the V3 domain, the cleavage sites in this domain are more polymorphic than other sites.

University of California, Santa Cruz, Santa Cruz, CA, USA

\section{Conclusion}

Our results suggest that cathepsin cleavage sites are highly conserved in gp120 and co-localize to regions recognized by bNAbs. These results are consistent with our hypothesis that the poor immunogenicity of gp120 epitopes results from protease digestion in vivo. Current studies are in progress to determine whether inactivation of these sites or enzymes may provide a new approach to improving the immunogenicity of epitopes recognized by bNAbs.

Published: 13 September 2012

doi:10.1186/1742-4690-9-S2-P297

Cite this article as: $Y u$ et al:: Antigen processing sites in gp120 are

conserved across HIV virus clades. Retrovirology 2012 9(Suppl 2):P297.

\section{Submit your next manuscript to BioMed Central and take full advantage of: \\ - Convenient online submission \\ - Thorough peer review \\ - No space constraints or color figure charges \\ - Immediate publication on acceptance \\ - Inclusion in PubMed, CAS, Scopus and Google Scholar \\ - Research which is freely available for redistribution

(c) 2012 Yu et al; licensee BioMed Central Ltd. This is an Open Access article distributed under the terms of the Creative Commons Attribution License (http://creativecommons.org/licenses/by/2.0), which permits unrestricted use, distribution, and reproduction in any medium, provided the original work is properly cited. 